\title{
Peran Mahasiswa dalam Pembangunan di Indonesia
}

\author{
Arnan Muflihady Martadinata \\ Prodi Teknik Perencanaan Wilayah dan Kota, Sekolah Arsitektur, Perencanaan dan Pengembangan \\ Kebijakan, Institut Teknologi Bandung \\ Jl. Let. Jend. Purn. Dr. (HC) Mashudi No.1, Sayang, Jatinangor, Sayang, Jatinangor, Kabupaten \\ Sumedang, Jawa Barat 45363 \\ email: arnanmm@gmail.com
}

\begin{abstract}
Continuing development by the government in Indonesia has a goal to advance the nation of Indonesia in the future and achieve the National goal. In order for this nation to continue to grow, development continues to be done by the government in all sectors, both political, economic, social, cultural, and others. In this case of course the government can not do it alone. To support the government in carrying out the development, it takes the role and participation of the community. One component of the community are students. This essay aims to discuss the conditions of development in Indonesia and the role that can be done by students in promoting development in Indonesia. Using literature study and adding images to strengthen the argument in this essay, it can be seen the role that students can take as the younger generation of the nation to play a role in national development
\end{abstract}

Keywords: roles, development, students, youth, national goals

\begin{abstract}
Abstrak. Pembangunan yang terus dilakukan oleh pemerintah di Indonesia mempunyai tujuan untuk memajukan bangsa Indonesia ke depannya dan mencapai tujuan Nasional. Agar bangsa ini terus berkembang, pembangunan terus dilakukan oleh pemerintah di semua sektor, baik politik, ekonomi, sosial, budaya, dan lain-lain. Dalam hal ini tentunya pemerintah tidak bisa melakukannya sendirian. Untuk mendukung pemerintah dalam melaksanakan pembangunan tersebut, dibutuhkan peran dan partisipasi dari masyarakat. Salah satu komponen masyarakat tersebut adalah mahasiswa. Esai ini bertujuan untuk membahas kondisi pembangunan di Indonesia dan peran yang bisa dilakukan oleh mahasiswa dalam memajukan pembangunan di Indonesia. Dengan menggunakan studi literaturs dan menambahkan gambar untuk memperkuat argumen dalam esai ini, dapat diketahui peran yang bisa dilakukan mahasiswa sebagai generasi muda penerus bangsa untuk berperan dalam pembangunan Nasional
\end{abstract}

Kata kunci: peran, pembangunan, mahasiswa, generasi muda, tujuan nasional

\section{Pendahuluan}

Menurut pasal 1 ayat 1 UndangUndang Dasar Negara Kesatuan Republik Indonesia tahun 1945 yang berbunyi "Negara Indonesia adalah negara kesatuan yang berbentuk Republik". Negara Indonesia sendiri merupakan negara kepulauan terbesar di dunia. Hal ini tentunya menjadi keuntungan dan keistimewaan tersendiri bagi Indonesia dibanding negara- negara lainnya. Dan dengan kondisi gografis yang seperti itu tentunya menjadi tantangan tersendiri bagi pemerintah dalam melakukan pembangunan di Indonesia ini.

Pemerintah tidak pernah berhenti melakukan pembangunan. Pembangunan yang dilakukan oleh pemerintah umumnya yang bersifat infrastruktur atau prasarana, yaitu 
bangunan fisik ataupun lembaga yang mempunyai kegiatan lain dibidang ekonomi, sosial budaya, politik daan pertahanan keamanan (B.S Muljana, 2001). Untuk mendukung pemerintah dalam melaksanakan pembangunan di Indonesia ini dibutuhkan peran dan partisipasi dari masyarakat. Masyarakat diharapkan turut ikut serta dalam memajukan pembangunan di Indonesia karena tujuan pemerintah melakukan pembangunan adalah untuk kesejahteraan masyarakat itu sendiri.

Salah satu komponen dalam masyarakat yang bisa berperan lebih bagi pembangunan dan kemajuan Indonesia adalah pemuda dan mahasiswa. Kalau kita melihat kembali sejarah, pemuda dan mahasiswa sebenarnya telah mempunyai peran yang penting bagi bangsa ini, dimulai dari pergerakan Budi Utomo tahun 1908, Sumpah Pemuda tahun 1928, proklamasi kemerdekaan tahun 1945, pergerakan pemuda, pelajar, dan mahasiswa tahun 1966, sampai dengan pergerakan mahasiswa pada tahun 1998 yang meruntuhkan kekuasaan Orde Baru selama 32 tahun sekaligus membawa bangsa Indonesia memasuki era reformasi. Fakta historis tersebut dapat menjadi salah satu bukti bahwa pemuda dan mahasiswa mampu berperan aktif bahkan menjadi pionir dalam proses perjuangan, pembaruan, dan pembangunan bangsa.

Pada tulisan ini akan dibahas mengenai pembangunan di Indonesia. Kemudian akan dibahas peran mahasiswa sebagai agent of change pembangunan di Indonesia, lalu peran mahasiswa sebagai pengawas dan penilai keberhasilan pembangunan yang dilakukan, selanjutnya akan dibahas mengenai peran mahasiswa bagi daerah terpencil dan tertinggal serta peran yang bisa dilakukan mahasiswa untuk memajukan daerah tersebut. Dan terakhir akan dibahas pula kesimpulan dari keseluruhan tulisan ini dan saran bagi permasalahan yang telah dijelaskan.

\section{Metode}

Penelitian dilakukan menggunakan metode studi literatur. Literatur yang digunakan adalah bukubuku mengenai pembangunan daerah, perencanaan pembangunan, serta buku mengenai gerakan mahasiswa sebagai referensi pembuatan jurnal ini.

\section{Hasil dan Pembahasan}

\section{Pembangunan di Indonesia}

Pembangunan menurut Siagian (1994), dapat diartikan sebagai suatu usaha atau rangkaian usaha pertumbuhan dan perubahan yang berencana dan dilakukan secara sadar oleh suatu bangsa, negara dan pemerintah, menuju modernitas dalam rangka pembinaan bangsa (nation building). Pembangunan dilakukan untuk mencapai tujuan tertentu yang telah direncanakan. Adapun tujuan dari pembangunan nasional tercantum dalam pembukaan UUD NKRI tahun 1945 alinea 4 yaitu melindungi segenap bangsa Indonesia dan seluruh tumpah darah Indonesia, serta untuk memajukan kesejahteraan umum, mencerdaskan kehidupan bangsa, dan ikut melaksanakan ketertiban dunia yang berdasarkan kemerdekaan, perdamaian abadi, dan keadilan sosial.

Agar bangsa ini terus berkembang, pembangunan terus dilakukan oleh pemerintah di semua sektor, baik politik, ekonomi, sosial, budaya dll. Dalam hal ini tentunya pemerintah tidak bisa melakukannya sendirian. Pelaku- pelaku pembangunan tersebut di Indonesia adalah pemerintah, rakyat, dan pengusaha. Pemerintah sebagai penyedia dana dan pemegang regulasi mengenai pembangunan yang 
akan dilakukan, rakyat sebagai indikator keberhasilan suatu pembangunan yang telah dilakukan sedangkan pengusaha sebagai investor atau penyedia dana selain dari pemerintah. Sebagai bagian dari masyarakat, mahasiswa bisa berperan sebagai pengawas pembangunan, bukan hanya sebagau indikator keberhasilan dari suatu pembangunan saja.

\section{Peran Mahasiswa dalam Pembangunan Indonesia}

Menurut Siswoyo (2007: 121) mahasiswa dapat didefinisikan sebagai individu yang sedang menuntut ilmu di perguruan tinggi, baik negeri ataupun swasta atau lembaga lain yang setingkat dengan perguruan tinggi. Peran mahasiswa sebagai pengawas dari suatu pembangunan yang dilakukan harus bisa menonjol karena mahasiswa dianggap oleh masyarakat sebagai orang yang memiliki pendidikan lebih tinggi dibandingkan yang lain, sehingga mereka yakin bahwa mahasiswa mampu menyampaikan aspirasi sebagai bentuk suara hatinya (Arsad Ismail, 2013). Mahasiswa sebagai kaum intelek dengan pemikirannya yang kritis dan analitis harus berani untuk mengeluarkan pendapatnya secara langsung kepada pemerintah apabila pembangunan yang dilakukan pemerintah merugikan rakyat atau tidak sesuai dengan tujuan pembangunan tersebut. Dengan begitu, akan terjadi perubahan dan pembaruan dalam pembangunan sebagai hasil dari pemikiran mahasiswa.

$$
\text { Mahasiswa mempunyai }
$$

kedudukan sebagai generasi muda penerus bangsa ini di masa yang akan datang kelak. Mahasiswa harus bisa menjadi pelopor masyarakat, memberikan perubahan- perubahan yang berdampak positif dan membangun kehidupan masyarakat serta menanamkan nilai- nilai positif dalam masyarakat. Dengan kata lain, mahasiswa dapat disebut sebagai agent of change. Mahasiswa sebagai generasi muda, mempunyai pemikiran- pemikiran dan ide- ide baru yang baru dan kreatif, untuk menyalurkan pemikiranpemikiran dan ide- ide tersebut banyak hal yang dilakukan mahasiswa seperti mengikuti organisasi di dalam / luar kampus dan mengikuti lomba seperti PKM (Pekan Kreatifitas Mahasiswa) yang diadakan oleh pemerintah. Mahasiswa megikuti organisasi untuk melatih softskill mereka karena selain Indeks Prestasi, kualitas penting yang dibutuhkan setelah lulus adalah softskill dan ini bisa didapatkan dari mengikuti organisasi ataupun lembaga- lembaga kemahasiswaan (Holil, 2009).

Peran mahasiswa sebagai agent of change bagi pembangunan bangsa ini dapat dimulai dari organisasi ataupun lembaga- lembaga di kampus yang diikuti. Di dalam organisasi atau lembaga tersebut mahasiswa dapat berkarya sesuai dengan kreatifitas mereka dan melakukan sesuatu bagi bangsa ini. Sebagai contoh dalam memeringati 2 tahun pemerintahan Jokowi-JK bulan Oktober tahun 2016 kemarin, mahasiswa dari berbagai penjuru Indonesia yang tergabung dalam BEM se-Indonesia melakukan aksi untuk menuntut janji- janji yang belum dilaksanakan oleh Jokowi-JK agar segera dilaksanakan. 


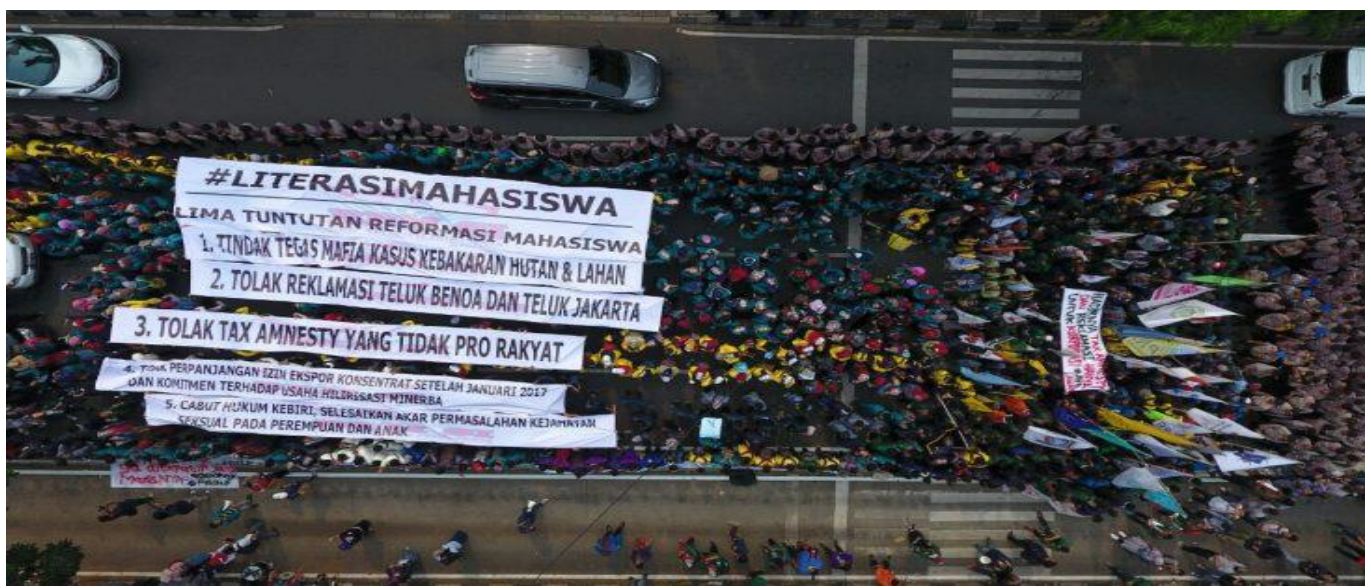

Gambar 1. Aksi mahasiswa dalam peringatan 2 tahun pemerintahan Jokowi-JK (Sumber: http : UNJkita.com diakses pada 4 April 2017 pukul 21.32 WIB)

Gambar tersebut merupakan aksi mahasiswa saat peringatan 2 tahun pemerintahan Jokowi-JK, pada saai itu mahasiswa menuntut beberapa hal terkait dengan kemajuan bangsa Indonesia. Hal ini menunjukkan bahwa mahasiswa bisa menjadi agent of change untuk terutama untuk pembangunan Indonesia ke depannya.

Kondisi pembangunan nasional saat ini belum sempurna karena pembangunan nasional saat ini masih bersifat jangka pendek dan relatif belum terselesaikan dengan kompleksitas permasalahan yang ada (Laili Marum, 2015). Hal disebabkan karena kondisi geografis Indonesia dan kurang optimalnya pemerintah dalam mengusahakan pembangunan nasional. Dengan kondisi gografis sebagai negara kepulauan terbesar di dunia dengan jumlah penduduk berkisar 237.641.326 jiwa ( menurut sensus BPS tahun 2010) tentunya tidak mudah bagi pemerintah unuk melakukan pembangunan secara merata.

Secara tidak langsung, pembangunan yang kurang merata tersebut juga disebabkan oleh kurangnya keinginanan mahasiswa untuk mengabdi dan memajukan daerah terpencil dan tertinggal setelah lulus dari
Daerah terpencil dan tertinggal membutuhkan suatu pionir bagi masyarakatnya untuk memajukan daerah tersebut. Sebagai kaum intelek dan generasi muda, mahasiswalah yang harus berperan.

Peran mahasiswa untuk memajukan daerah terpencil tidak hanya bisa dilakukan setelah lulus atau menyelesaikan pendidikan formalnya, tetapi saat masih menjalani pendidikannya mahasiswa pun bisa berperan untuk daerah terpencil. Cara yang bisa dilakukan yaitu mengadakan pengabdian dan pelatihan jangka panjang bagi daerah terpencil dan tertinggal untuk meningkatkan keahlian yang dimiliki masyarakatnya dalam bidang kewirausahaan dan lainnya. Jangka panjang yang dimaksud adalah melakukan pelatihan secara berkala hingga masyarakatnya mempunyai kemampuan dan kemandirian dalam menjalankan usah sendiri. Hal ini akan memicu terjadinya pembangunan bagi daerah tersebut dan membuat daerah tersebut semakin maju.

Sudah seharusnya mahasiswa mengabdi bagi bangsa ini terutama bagi daerah terpencil dan tertinggal. Hal tersebut mengingat saat ini pemerintah telah berusaha memajukan pendidikan 
perguruan tinggi di Indonesia dan memudahkan masyarakat untuk berkuliah dengan cara memberikan subsidi uang kuliah bagi perguruan tinggi di Indonesia. Sebagai contoh, berdasarkan data Kementrian Riset Teknologi dan Pendidikan Tinggi (Ristekdikti), dana yang dikeluarkan pemerintah untuk Biaya Operasional Perguruan Tinggi Negeri (BOPTN) pada tahun 2016 sekitar Rp 4,5 triliun dari total anggaran untuk pendidikan nasional yang mencapai Rp 419,2 triliun. Selain memberikan subsidi bagi perguruan tinggi negeri, dalam UU no. 12 tahun 2012 tentang Pendidikan Tinggi pasal 76 ayat 1 disebutkan bahwa pemerintah, pemerintah daerah, dan / atau perguruan tinggi berkewajiban memenuhi hak mahasiswa yang kurang mampu secara ekonomi untuk dapat menyelesaikan studinya sesuai dengan peraturan akademik. Tentunya seluruh dana yang digunakan juga berasal dari pajak yang dikeluarkan oleh masyarakat Indonesia sendiri karena pada akhirnya setelah selesai menempuh jenjang pendidikan di perguruan tinggi, para mahasiswa diharapkan dapat kembali dan membawa perubahan di masyarakat.

\section{Simpulan}

Dari pembahasan diatas, dapat disimpulkan bahwa dalam melaksanakan pembangunan nasional pemerintah membutuhkan partisipasi dari seluruh pelaku pembangunan. Pemerintah membutuhkan partisipasi agar pembangunan yang dilakukan terarah dan sesuai dengan apa yang dibutuhkan dan diharapkan oleh masyarakat, selain itu juga agar pemerintah dapat mengetahui bagaimana keberhasilan dari pembangunan yang telah dilakukan bagi bangsa ini. Mahasiswa sebagai generasi muda yang mempunyai pemikiranpemikiran yang baru dan kreatif,dapat mengambil peran unutuk membantu pemerintah dalam melakukan pembangunan dan memajukan bangsa Indonesia ini.

Peran mahasiswa bagi pembangunan nasional yaitu mahasiswa sebagai agent of change atau pembawa perubahan bagi masyarakat, mahasiswa sebagai pengawas pembangunan dan penilai keberhasilan dari suatu pembangunan yang telah dilakukan, dan pengabdian bagi masyarakat daerah terpencil dan tertinggal agar membuka potensi yang dimilik daerah tersebut sehingga membuat daerah tersebut menjadi maju. Untuk itu, mahasiswa seharusnya bersikap proaktif terhadap pemerintah dan bangsa Indonesia. Melihat kondisi pembangunan di Indonesia saat ini, sudah saatnya mahasiswa mengambil peran berusaha untuk membuat bangsa ini lebih baik ke depannya. Karena bagaimanapun yang akan menjalankan pemerintahan bangsa ini di masa yang akan datang adalah pemuda- pemuda dan mahasiswamahasiswa Indonesia saat ini.

\section{Daftar Pustaka}

Effendi, Bachtiar. (2002) Pembangunan Daerah Otonom Berkeadilan (Cetakan Pertama). Yogyakarta: PT. Uhindo dan Offset

Wrihatnolo, Randy R. (2009). Konsep dan Pendekatan Pembangunan. Jakarta : Institute for Development and Policy Study.

Sarwono dan Wirawan, Sarlito. (1978) .Perbedaan Antara Pemimpin dan Aktivis dalam Gerakan Protes Mahasiswa. Jakarta : Bulan Bintang.

Djamaluddin, H. M. Arief. (2006). Diktat Kuliah Perencanaan Pembangunan. Universitas Borobudur. Jakarta.

Undang Undang Dasar Negara Kesatuan Republik Indonesia tahun 1945 
6 Arnan Muflihady Martadinata

UU No. 12 tahun 2012 tentang perguruan tingi

DoI: https://doi.org/10.29313/idea.v0i0.4168 